\title{
The association of estrogen-signaling pathways and susceptibility to open-angle glaucoma
}

\author{
Zulvikar Syambani Ulhaq®
}

\begin{abstract}
Background: Glaucoma is a complex multivariate disorder characterized by retinal ganglion cell (RGC) loss and optic nerve degeneration. Evidence suggests the role of estradiol $\left(E_{2}\right)$ and the etiology of glaucoma. Therefore, this present study evaluates the association between estrogen-signaling pathways and the risk of open-angle glaucoma $(\mathrm{OAG})$.
\end{abstract}

Results: Meta-analysis was performed from available studies that investigated intraocular pressure (IOP) in patients treated with or without hormone replacement therapy (HRT) and studies that evaluated the associations between estrogen receptor (ER) polymorphisms and the risk of OAG. The pooled result showed that HRT had a positive effect in lowering IOP. Moreover, ER $\beta$ polymorphisms showed a significant association with the risk of OAG.

Conclusion: This report supports the notion that estrogen-signaling pathways play a pivotal role in the development of OAG.

Keywords: Estradiol, Estrogen receptor, Polymorphisms, Hormone replacement therapy, Intraocular pressure, Openangle glaucoma

\section{Background}

Glaucoma is a complex multivariate disease characterized by retinal ganglion cell (RGC) loss and optic nerve degeneration [1]. A high intraocular pressure (IOP) is observed in the glaucomatous eye as a result of trabecular meshwork (TM) outflow resistance [2]. It is well known that open-angle glaucoma (OAG) is the most common type of glaucoma [3]. Several risk factors have been identified and associated with the etiology of glaucoma including elevation of IOP, immune and inflammatory mediators, and oxidative stress [4]. The number of people with glaucoma worldwide is projected to be 111.8 million in 2040, particularly in the Asian and African populations [5]. Further, the prevalence of OAG is likely observed in men and linearly increases with age [6], suggesting that female sex steroid hormones contribute to the development of OAG.

Correspondence: zulhaq@kedokteran.uin-malang.ac.id

Department of Biomedical Science, Faculty of Medicine and Health Sciences, Maulana Malik Ibrahim Islamic State University of Malang, Batu, East Java 65151, Indonesia

(c) The Author(s). 2020 Open Access This article is distributed under the terms of the Creative Commons Attribution 4.0 International License (http://creativecommons.org/licenses/by/4.0/), which permits unrestricted use, distribution, and reproduction in any medium, provided you give appropriate credit to the original author(s) and the source, provide a link to the Creative Commons license, and indicate if changes were made.
Estradiol $\left(E_{2}\right)$ is a predominant form of estrogen and is considered as the major female sex steroid hormone. $\mathrm{E}_{2}$ biosynthesis is catalyzed from testosterone by the ratelimiting enzyme aromatase, encoded by the cyp19a gene [7-10]. $E_{2}$-mediated effects are mainly modulated by two types of estrogen receptor (ER), ER $\alpha$ and $\beta$. Because estrogen signaling is dependent on its receptor, subtle changes in the DNA sequence (polymorphism) of ER genes may result in different responses to $E_{2}$ [11]. Therefore, understanding ER genes polymorphisms are necessary in regard to their role in glaucoma pathogenesis.

Previously, it has been reported that ER $\beta$ is predominantly expressed in the central nervous system (CNS) [7]. Interestingly, in the retina, the expression of $E R \beta$ is strongly localized in the ganglion cell layer (GCL) [12]. Furthermore, the administration of $E_{2}$ suppresses ganglion cell loss and improve contrast sensitivity in glaucoma model [13-16], implying that $E_{2}$ exerts a neuroprotective effect on the retina and optic nerve and possibly is becoming an important approach for glaucoma treatment. \\ SpringerOpen}


A number of studies have been showing a positive impact of hormone replacement therapy (HRT) in lowering IOP and the prevalence of glaucoma in post-menopausal women $[17,18]$, although the correlation between $E_{2}$ and glaucoma has been studied to some extent. Interestingly, however, genotypic distributions of ER and the effect of HRT among various glaucoma patients vary across studies and have not been systemically analyzed. Thus, this report will highlight how estrogen plays an important role in the pathophysiology of OAG.

\section{Methods}

A literature search was conducted from major international databases until September 2019.

\subsection{Effect of HRT in lowering IOP}

To evaluate the efficacy of HRT in lowering IOP, the selection criteria were as follows: (1) comparing the IOP of HRT-treated patients with controls, (2) patients were female in a menopausal period, (3) a case-control design, and (4) pre-post treatment evaluation. Pooled standardized mean difference (SMD) with 95\% confidence interval (CI) was used to assess the IOP between patients with HRT and controls. Heterogeneity among studies was evaluated using $Q$ test and $I^{2}$ statistic. Subgroup analysis based on the methodological design was performed to investigate if heterogeneity existed. Begg's funnel plots and Egger's regression test were used to assess publication bias. An analysis with $P<0.05$ is considered statistically significant.

\subsection{Association of ER polymorphism and glaucoma}

To analyze the association of ER polymorphism and glaucoma, the selection criteria were as follows: (1) evaluating the associations between ER polymorphisms and the risk of OAG, (2) glaucoma patients and control subjects were a combination of male and female, and (3) a case-control design. The genotypic frequency for the ER polymorphisms was tested by Hardy-Weinberg equilibrium (HWE). The associations between the ER polymorphisms and OAG risks were estimated by calculating the pooled odds ratio (OR) and 95\% CI. Heterogeneity was evaluated with $Q$ test and $I^{2}$. Begg's funnel plots and Egger's regression test were used to evaluate publication bias. The value of $<0.05$ was indicative of statistical significance.

\section{Results}

Aromatase, encoded by the cyp19a1 (cytochrome P450 19A1) gene, is a rate-limiting enzyme for $E_{2}$ biosynthesis [7-10]. The expression and activity of cyp19a1 are significantly decreased in menopausal women [19]. At some point, a previously published article reviews the role of HRT in regulating IOP [18]. However, a meta- analysis was not performed. In this current study, 10 studies included in this meta-analysis measured the IOP from menopausal women with or without HRT (Table 1). A meta-analysis of IOP in patients with HRT and the controls were shown in Fig. 1a. The pooled results indicated HRT-treated patients had lower IOP than controls or pre-treatment $(\mathrm{SMD}=-0.39,95 \% \mathrm{CI}=-0.52$ to $0.26, P<0.00001)$. There was a significant heterogeneity $\left(I^{2}=84 \%, P<0.00001\right)$ in pooled studies. Duration treatment was of considerable effect on heterogeneity $(b=$ 0.162; $P<0.041$ ). Begg's funnel plot (Fig. 1b) and Egger's test showed that there was a publication bias between studies $(P=0.001)$, which is possibly caused by the heterogeneity of studies. Therefore, a trim and fill method was carried out but did not leverage the results and the outcome remains similar, indicating that it was not affected by publication bias.

Estrogen-mediated effects are modulated by ER [7]. Two studies investigating the associations between ER polymorphisms and the risk of OAG were evaluated. Two and four polymorphisms occurred in the ER $\alpha$ and ER $\beta$ genes, respectively (Table 2). All of the polymorphisms complied with the HWE $(P>0.05)$. The pooled results showed that there was no significant association between ER $\alpha$ gene polymorphisms with the risks of OAG. A significant association was observed between ER $\beta$ gene polymorphisms with the risk of OAG (indicated by an asterisk in Table 3). Compared to the TC/ CC genotypes, the TT genotype of ER $\beta$ rs1256031 showed a $36 \%$ decrease in the odd's ratio $(O R=0.64$, 95\% CI 0.47-0.88, $P=0.006$ ). Moreover, the TT genotype of ER $\beta$ rs1256031 also significantly decreased the risk of OAG by $39 \%$ compared to the TC genotype (OR $=0.61,95 \% \mathrm{CI} 0.44-0.86, P=0.005)$, indicating that the $\mathrm{C}$ allele increased the risk of OAG. On the other hand, the $G$ allele of ER $\beta$ rs 4986938 was associated with the risk of OAG $(\mathrm{OR}=1.37,95 \% \mathrm{CI} 1.04-1.82, P=0.03)$, while the A allele was protective. No publication bias was observed for the association of the ER polymorphisms and the OAG risks $(P>0.05)$.

\section{Discussion}

In this present study, it showed that HRT act as an IOPlowering agent in menopausal women. Indeed, a low level of $E_{2}$ has been suggested to be associated with an increased IOP [6]. Moreover, a high IOP and degenerated RGCs are observed in female cyp19a1 knockout mice [32], thereby suggesting that estrogen is necessary for regulating aqueous humor dynamics. Currently available treatments for glaucoma are to control and maintain the IOP. However, most of the drugs are reducing IOP by modifying aqueous dynamic [33], but not necessarily treat the underlying mechanisms of high IOP, which is mainly caused by TM outflow resistance [2]. It 
Table 1 Summary of the studies for the IOP between HRT-treated patients and the control subjects

\begin{tabular}{|c|c|c|c|c|c|c|c|c|c|c|}
\hline \multirow[t]{3}{*}{ Author } & \multirow[t]{3}{*}{ Country } & \multirow{3}{*}{$\begin{array}{l}\text { Mean } \\
\text { age } \\
\text { (year) }\end{array}$} & \multirow{3}{*}{$\begin{array}{l}\text { Duration } \\
\text { of } \\
\text { treatment }\end{array}$} & \multirow[t]{3}{*}{ Type } & \multicolumn{6}{|c|}{$\mathrm{IOP}(\mathrm{mmHg})$} \\
\hline & & & & & \multicolumn{3}{|l|}{ HRT } & \multicolumn{3}{|c|}{ non-HRT/pre } \\
\hline & & & & & $n$ & Mean & SD & $n$ & Mean & SD \\
\hline Abramov et al. 2005 (a) [20] & Israel & 66.45 & 12 months & $N A(R O)$ & 107 & 15.2 & 0.4 & 107 & 15.5 & 0.4 \\
\hline Abramov et al. 2005 (b) & & & & NA (LO) & 107 & 15.3 & 0.5 & 107 & 15.2 & 0.2 \\
\hline Affinito et al. 2003 (a) [21] & Italy & 53.7 & 3 months & Estradiol + medroxyprogesterone acetate & 24 & 14.1 & 2 & 24 & 16.6 & 2.3 \\
\hline Affinito et al. 2003 (b) & & & 6 months & & 24 & 14.1 & 2.1 & 24 & 16.6 & 2.4 \\
\hline Altintaş et al. 2004 (a) [22] & Turkey & 46.1 & 2 months & NA & 20 & 12.33 & 1.76 & 24 & 14.66 & 1.71 \\
\hline Altintaş et al. 2004 (b) & & & & & 20 & 12.33 & 1.76 & 20 & 16.16 & 2.32 \\
\hline Coksuer et al. 2011 [23] & Turkey & $\begin{array}{l}45- \\
60^{*}\end{array}$ & 6 months & Estradiol + drospirenone & 34 & 13.4 & 2.7 & 34 & 14.1 & 2.8 \\
\hline Guaschino et al. 2003 [24] & Italy & 59.9 & 12 months & Estradiol + dydrogesterone & 40 & 14.8 & 3.2 & 40 & 14.9 & 4.3 \\
\hline Özcan et al. 2017 (a) [25] & Turkey & 49.9 & 6 months & NA & 61 & 13.9344 & 1.47 & 76 & 15.41 & 1.76 \\
\hline Özcan et al. 2017 (b) & & & & & 61 & 13.9344 & 1.47 & 76 & 14.35 & 1.4 \\
\hline Sator et al. 1997 (a) [26] & Austria & 55.7 & 1 week & $\begin{array}{l}\text { Estradiol + medroxyprogesterone acetate } \\
(\mathrm{RO})\end{array}$ & 25 & 14.9 & 2 & 25 & 15.2 & 2.6 \\
\hline Sator et al. 1997 (b) & & & & $\begin{array}{l}\text { Estradiol + medroxyprogesterone acetate } \\
(\llcorner O)\end{array}$ & 25 & 15.2 & 2.4 & 25 & 15.9 & 2.6 \\
\hline Sator et al. 1997 (c) & & & 1 month & $\begin{array}{l}\text { Estradiol + medroxyprogesterone acetate } \\
(\mathrm{RO})\end{array}$ & 25 & 14.4 & 2.1 & 25 & 15.2 & 2.6 \\
\hline Sator et al. 1997 (d) & & & & $\begin{array}{l}\text { Estradiol + medroxyprogesterone acetate } \\
(\mathrm{LO})\end{array}$ & 25 & 14.2 & 2.3 & 25 & 15.9 & 2,6 \\
\hline Sator et al. 1997 (e) & & & 3 months & $\begin{array}{l}\text { Estradiol + medroxyprogesterone acetate } \\
(\mathrm{RO})\end{array}$ & 25 & 13.8 & 1.9 & 25 & 15.2 & 2.6 \\
\hline Sator et al. 1997 (f) & & & & $\begin{array}{l}\text { Estradiol + medroxyprogesterone acetate } \\
(\text { LO) }\end{array}$ & 25 & 14.2 & 2.3 & 25 & 15.9 & 2.6 \\
\hline Tint et al. 2010 (a) [27] & Scotland & 59.35 & NA & Estradiol only & 33 & 11.81 & 2.91 & 172 & 13.25 & 2.85 \\
\hline Tint et al. 2010 (b) & & & & Combined & 58 & 11.87 & 2.51 & 172 & 13.25 & 2.85 \\
\hline Toker et al. 2003 [28] & Turkey & 52.4 & $\begin{array}{l}1.5 \\
\text { months }\end{array}$ & NA & 30 & 13.29 & 2.28 & 32 & 13.56 & 2.5 \\
\hline $\begin{array}{l}\text { Vajaranant et al. } 2016 \text { (a) } \\
\text { [29] }\end{array}$ & USA & 71.875 & $\begin{array}{l}5 \pm 1 \\
\text { years }\end{array}$ & Estradiol (RO) & 808 & 15.4 & 3.2 & 860 & 15.8 & 3.3 \\
\hline Vajaranant et al. 2016 (b) & & & & Estradiol + progestin $(\mathrm{RO})$ & 1397 & 15.6 & 3 & 1282 & 15.7 & 3.1 \\
\hline Vajaranant et al. 2016 (c) & & & & Estradiol (LO) & 808 & 15.3 & 3.1 & 860 & 15.9 & 3.2 \\
\hline Vajaranant et al. 2016 (d) & & & & Estradiol + progestin (LO) & 1397 & 15.7 & 3 & 1282 & 15.7 & 3 \\
\hline
\end{tabular}

$n$ and SD represented the number of samples and standard deviation of IOP, respectively

$N A$ not available, $R O$ right ocular, $L O$ left ocular

*Data presented as range

has been reported that an increase in aqueous outflow resistance is closely associated with fibrotic changes in TM [34]. Thus, drugs targeting IOP with anti-fibrotic properties may be useful for treating glaucoma.

Fibrotic changes in OAG patients are characterized by extracellular matrix (ECM) deposition in TM, which was mediated by transforming growth factor- $\beta$ (TGF- $\beta$ ) 1 and 2, with levels significantly elevated in the aqueous humor of patients with OAG [35-37]. On the other hand, the administration of $E_{2}$ has been reported to suppress TGF- $\beta$-induced activation of Sma and MADrelated protein 3 (Smad3) activity [38]. Further, $E_{2}$ prevents cardiac fibrosis through the ER $\beta$ signaling pathway by inhibiting the effects of angiotensin II (AngII) and endothelin-1 (ET-1)-induced pro-fibrotic signaling in female mice [39]. Therefore, a combination of drugs lowering IOP with estrogen replacement therapy seems promising in targeting normal IOP for menopausal women with glaucoma.

It was showed that ER $\beta$ rs1256031 and rs4986938 polymorphisms were associated with OAG risks, but not ER $\alpha$. A study from Pasquale et al. was not included in this meta-analysis because genotype frequency was not provided. However, they reported that both ER $\alpha$ and ER $\beta$ play an important role in high-tension glaucoma (HTG) and normal-tension glaucoma (NTG) among 


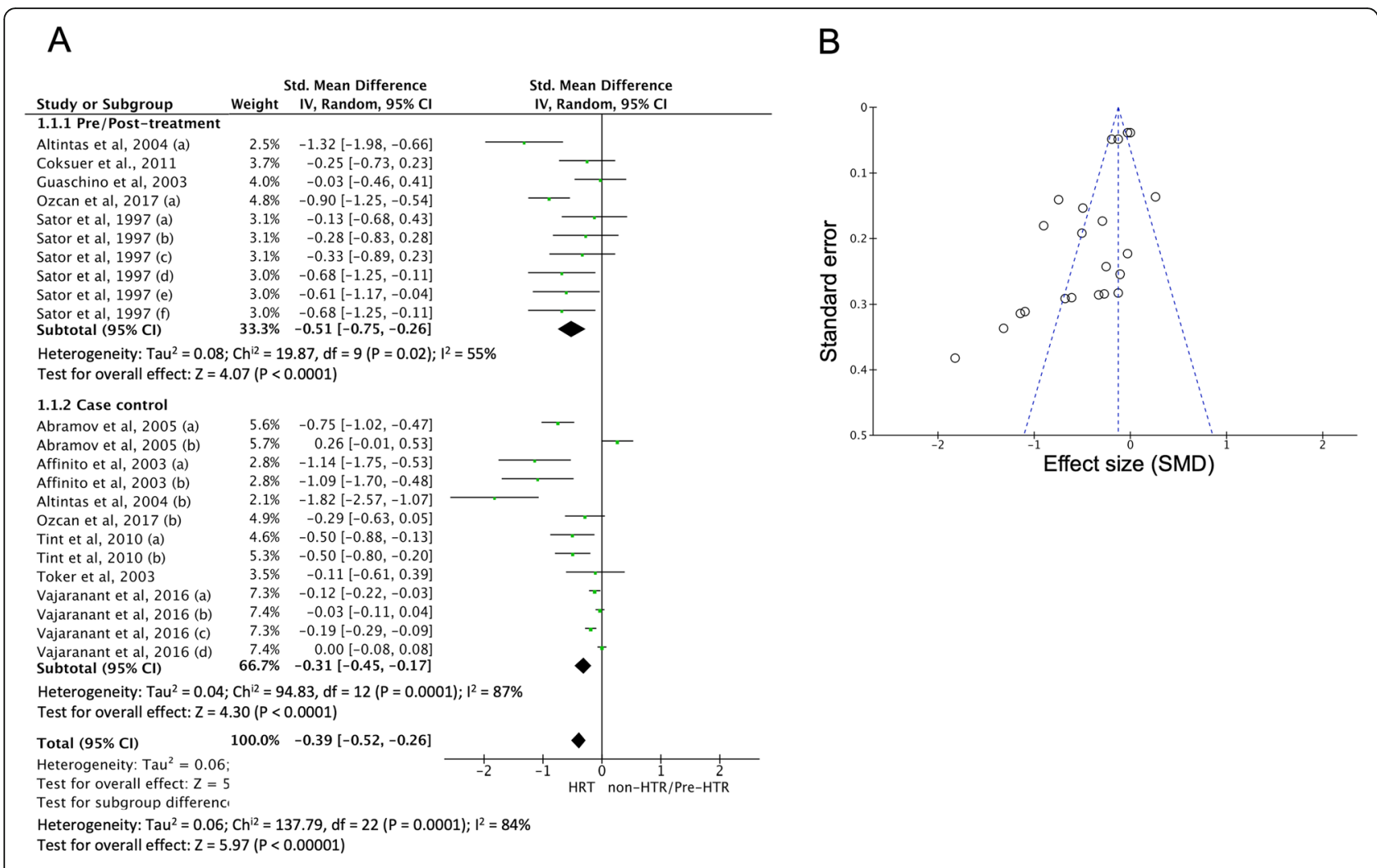

Fig. 1 a Forest plot of the pooled studies evaluating IOP in HRT-treated patients and controls. b Begg's funnel plot to evaluate publication bias

Table 2 Characteristics of individual studies for the associations between ER polymorphisms and the risk of OAG

\begin{tabular}{|c|c|c|c|c|c|c|c|c|c|c|c|c|}
\hline \multirow[t]{3}{*}{ Author } & \multirow[t]{3}{*}{ Country } & \multirow[t]{3}{*}{ Polymorphism } & \multirow[t]{3}{*}{ Type } & \multirow{3}{*}{$\begin{array}{l}\text { Gender } \\
(\mathrm{f} / \mathrm{m})^{\mathrm{a}}\end{array}$} & \multirow[t]{3}{*}{$\mathrm{Age}^{\mathrm{b}}$} & \multicolumn{6}{|c|}{ Genotype distribution $^{c}$} & \multirow[t]{3}{*}{$P_{\mathrm{HWE}}{ }^{\mathrm{d}}$} \\
\hline & & & & & & \multicolumn{3}{|c|}{ Case } & \multicolumn{3}{|c|}{ Control } & \\
\hline & & & & & & 11 & 12 & 22 & 11 & 12 & 22 & \\
\hline \multicolumn{13}{|l|}{ ERa } \\
\hline Kosior-Jarecka et al. 2019 [30] & Poland & rs12154178 & NTG & $100 / 43$ & $74 / \mathrm{NA}$ & 77 & 57 & 6 & 90 & 68 & 6 & 0.111733 \\
\hline Kosior-Jarecka et al. 2019 & Poland & & HTG & $63 / 29$ & 77.5/NA & 50 & 36 & 7 & 90 & 68 & 6 & 0.111733 \\
\hline Kosior-Jarecka et al. 2019 & Poland & rs1884054 & NTG & $100 / 43$ & $74 / \mathrm{NA}$ & 61 & 57 & 17 & 79 & 67 & 19 & 0.410095 \\
\hline Kosior-Jarecka et al. 2019 & Poland & & HTG & $63 / 29$ & 77.5/NA & 46 & 36 & 6 & 79 & 67 & 19 & 0.410095 \\
\hline \multicolumn{13}{|l|}{ ERß } \\
\hline Kosior-Jarecka et al. 2019 & Poland & rs1268656 & NTG & $100 / 43$ & $74 / \mathrm{NA}$ & 88 & 36 & 8 & 124 & 33 & 5 & 0.142854 \\
\hline Kosior-Jarecka et al. 2019 & Poland & & HTG & $63 / 29$ & $77.5 \mathrm{NA}$ & 66 & 17 & 5 & 124 & 33 & 5 & 0.142854 \\
\hline Kosior-Jarecka et al. 2019 & Poland & rs7159462 & NTG & $100 / 43$ & 74/NA & 102 & 25 & 5 & 142 & 22 & 1 & 0.883193 \\
\hline Kosior-Jarecka et al. 2019 & Poland & & HTG & $63 / 29$ & $77.5 / \mathrm{NA}$ & 75 & 13 & 1 & 142 & 22 & 1 & 0.883193 \\
\hline Mabuchi et al. 2010 [31] & Japan & rs1256031 & NTG & $326 / 290$ & $63.75 / 65.45$ & 59 & 107 & 47 & 49 & 84 & 58 & 0.101595 \\
\hline Mabuchi et al. 2010 & Japan & & HTG & $326 / 290$ & $63.35 / 65.45$ & 53 & 113 & 46 & 49 & 84 & 58 & 0.101595 \\
\hline Mabuchi et al. 2010 & Japan & rs4986938 & NTG & $326 / 290$ & $63.75 / 65.45$ & 161 & 49 & 3 & 136 & 48 & 7 & 0.294793 \\
\hline Mabuchi et al. 2010 & Japan & & HTG & $326 / 290$ & $63.35 / 65.45$ & 167 & 40 & 5 & 136 & 48 & 7 & 0.294793 \\
\hline
\end{tabular}

NA not available, NTG normal-tension glaucoma, HTG high-tension glaucoma

${ }^{\mathrm{a}}$ Gender based on type of glaucoma

${ }^{\mathrm{b}}$ The mean age of case and control

$c_{1}$ represents the common allele, while 2 represents the minor allele

${ }^{\mathrm{d}} P$ for HWE equilibrium test in controls 
Table 3 Meta-analysis for the association between ER polymorphisms and the risk of OAG

\begin{tabular}{llllll}
\hline Contrast & Number of studies & OR & $95 \% \mathrm{Cl}$ & $P^{2}(\%)$ & $P$ value \\
\hline ERa rs12154178 & & & & & \\
A vs C & 2 & 0.97 & $0.72-1.31$ & 0 & 0.84 \\
AA vs AC/CC & 2 & 0.98 & $0.70-1.38$ & 0 & 0.92 \\
CC vs AA/AC & 2 & 1.60 & $0.72-3.59$ & 0 & 0.25 \\
CC vs AA & 2 & 1.58 & $0.70-3.58$ & 0 & 0.27 \\
CC vs AC & 2 & 1.63 & $0.71-3.74$ & 0 & 0.25 \\
ERa rs1884054 & & & & & \\
A vs C & 2 & 1.01 & $0.75-1.36$ & 0 & 0.95 \\
AA vs AC/CC & 2 & 1.02 & $0.72-1.42$ & 0 & 0.93 \\
CC vs AA/AC & 2 & 0.86 & $0.45-1.63$ & 21 & 0.64 \\
CC vs AA & 2 & 0.85 & $0.41-1.77$ & 32 & 0.67 \\
CC vs AC & 2 & 0.96 & $0.79-1.15$ & 0 & 0.61 \\
ERß rs1268656 & & & & & \\
T vs G & 2 & 1.49 & $1.01-2.21$ & 0 & 0.05 \\
Tा vs GT/GG & 2 & 1.58 & $0.83-3.02$ & 62 & 0.17 \\
GG vs TT/GT & 2 & 0.73 & $0.49-1.08$ & 1 & 0.11 \\
GG vs TT & 2 & 2.08 & $0.88-4.88$ & 0 & 0.09 \\
GG vs GT & 2 & 1.66 & $0.67-4.11$ & 0 & 0.27 \\
ERß rs7159462 & & & & & \\
C vs T & 2 & 0.70 & $070-1.10$ & 0 & 0.12 \\
CC vs CT/TT & 2 & 0.66 & $0.42-1.05$ & 0 & 0.08 \\
TT vs CC/CT & 2 & 4.05 & $0.73-22.30$ & 0 & 0.11 \\
$\pi$ T vs CC & 2 & $0.77-23.55$ & 0 & 0.10 \\
TT vs CT & 2 & 3.07 & $0.53-17.72$ & 0 & 0.21
\end{tabular}

ERß rs 1256031

\begin{tabular}{|c|c|c|c|c|}
\hline C vs T & 2 & 1.20 & $0.99-1.46$ & 0 \\
\hline CC vs TC/TT & 2 & 1.15 & $0.84-1.58$ & 0 \\
\hline$\pi$ vs $\mathrm{CC} / \mathrm{TC} \mathrm{C}^{*}$ & 2 & 0.64 & $0.47-0.88$ & 0 \\
\hline TT vs CC & 2 & 0.70 & $0.48-1.03$ & 0 \\
\hline$\Pi$ vs TC* & 2 & 0.61 & $0.44-0.86$ & 0 \\
\hline
\end{tabular}

ERß rs4986938

\begin{tabular}{llllll} 
G vs A* & 2 & 1.37 & $1.04-1.82$ & 0 & 0.03 \\
GG vs GA/AA & 2 & 1.37 & $1.00-1.88$ & 0 & 0.05 \\
AA vs GG/GA & 2 & 0.51 & $0.21-1.24$ & 0 & 0.14 \\
AA vs GG & 2 & 0.48 & $0.20-1.16$ & 0 & 0.10 \\
AA vs GA & 2 & 0.63 & $0.25-1.59$ & 0 & 0.33 \\
\hline${ }^{*} P<0.05$ & & & & &
\end{tabular}

women, respectively [40]. Interestingly, ER modulates cyp19a1 expression which turns to create a positive loop between estradiol-aromatase [7]. Thus, ER polymorphisms may affect the physiological functions of estrogen in regulating aromatase and its product which later contributes to the development of OAG. Another possibility is that cyp1b1 (cytochrome P450 1B1) is regulated by ER [41], and the downregulation of this gene is correlated with OAG and oxidative stress in TM $[42,43]$, although conflicting results regarding the role of polymorphism in cyp $1 b 1$ and the risk of OAG between studies were documented [40, 42, 44, 45]. However, the loss of function in cyp $1 b 1$ variants, particularly c.1064 1076del, p.(Arg355Hisfs*69), seems to be associated with an increased risk for OAG [45]. Moreover, it is possible to hypothesize that estrogen might be modulated by cyp 1 b1 in regulating IOP.

\section{Conclusion}

In conclusion, this report shows that estrogen-signaling pathways are associated with the risk of OAG. Screening of hormonal status might be useful for the early detection of OAG.

\section{Abbreviations}

A: Adenine; C: Cytosine; Cl: Confidence interval; CNS: Central nervous system; cyp19a1: Cytochrome P450 19A1; cyp1b1: Cytochrome P450 1B1; E2: Estradiol; ECM: Extracellular matrix; ER: Estrogen receptor; G: Guanine; GCL: Ganglion cell layer; HRT: Hormone replacement therapy; HWE: Hardy-Weinberg equilibrium; IOP: Intraocular pressure; OAG: Open-angle glaucoma; RGC: Retinal ganglion cell; Smad3: Sma and MAD-related protein 3; SMD: Standardized mean difference; T: Thymine; TGF: Transforming growth factor; TM: Trabecular meshwork

\section{Acknowledgements}

Not applicable

\section{Author's contributions}

ZU designed, performed, analyzed, and wrote the manuscript. The author read and approved the final manuscript.

\section{Author's information}

Zulvikar Syambani Ulhaq is a lecturer at the Department of Biomedical Science, Faculty of Medicine and Health Sciences, Maulana Malik Ibrahim Islamic State University of Malang, Indonesia. His current interests are neuroestrogen and neuro-ophthalmology. Email: zulhaq@kedokteran.uin-malang.ac.id

\section{Funding}

The author received no specific funding for this work.

Availability of data and materials

All data and supplementary materials are available in the manuscript.

Ethics approval and consent to participate

Not applicable

Consent for publication

Not applicable

\section{Competing interests}

The author declares that he has no competing interest.

Received: 26 November 2019 Accepted: 6 January 2020

Published online: 20 February 2020

\section{References}

1. Takai Y, Tanito M, Ohira A (2012) Multiplex cytokine analysis of aqueous humor in eyes with primary open-angle glaucoma, exfoliation glaucoma, and cataract. Invest Ophthalmol Vis Sci 53:241-247. https://doi.org/10.1167/ iovs.11-8434 
2. Tamm ER, Fuchshofer $R$ (2007) What increases outflow resistance in primary open-angle glaucoma? Surv Ophthalmol 52(Suppl 2):S101-S104. https://doi. org/10.1016/j.survophthal.2007.08.002

3. Yumori JW, Cadogan MP (2011) Primary open-angle glaucoma: clinical update. J Gerontol Nurs 37(3):10-15. https://doi.org/10.3928/0098913420110210-01

4. Ulhaq, Z.S (in press). Chemokine IL-8 level in aqueous humor of open-angle glaucoma: a meta-analysis. Arch Soc Esp Oftalmol 2019.

5. Tham YC, Li X, Wong TY, Quigley HA, Aung T, Cheng CY (2014) Global prevalence of glaucoma and projections of glaucoma burden through 2040: a systematic review and meta-analysis. Ophthalmology 121(11):2081-2090. https://doi.org/10.1016/j.ophtha.2014.05.013

6. Rudnicka AR, Mt-Isa S, Owen CG, Cook DG, Ashby D (2006) Variations in primary open-angle glaucoma prevalence by age, gender, and race: a Bayesian meta-analysis. Invest Ophthalmol Vis Sci 47(10):4254-4261. https:// doi.org/10.1167/iovs.06-0299

7. Ulhaq ZS, Kishida M (2018) Brain aromatase modulates serotonergic neuron by regulating serotonin levels in zebrafish embryos and larvae. Front Endocrinol (Lausanne) 9:230. https://doi.org/10.3389/fendo.2018.00230

8. Ulhaq ZS (2019) Aromatase and neuroregeneration. Malang Neurol J 5:4850. https://doi.org/10.21776/ub.mnj.2019.005.01.9

9. Ulhaq ZS (2019) Estrogen - serotonin interaction and its implication on insulin resistance. Alex J Med 55(1):76-81. https://doi.org/10.1080/20905068. 2019.1670413

10. Ulhaq ZS (2019) Brain aromatase modulates cardiac functions in embryonic zebrafish. Int J Vet Sci Med 7(1):31-34. https://doi.org/10.1080/23144599. 2019.1675287

11. de Voogd S, Wolfs RC, Jansonius NM, Uitterlinden AG, Pols HA, Hofman A et al (2008) Estrogen receptors alpha and beta and the risk of open-angle glaucoma: the Rotterdam Study. Arch Ophthalmol 126(1):110-114. https:// doi.org/10.1001/archopht.126.1.110

12. Munaut $C$, Lambert $V$, Noël A, Frankenne F, Deprez M, Foidart JM et a (2001) Presence of oestrogen receptor type beta in human retina. $\mathrm{Br} J$ Ophthalmol 85(7):877-882. https://doi.org/10.1136/bjo.85.7.877

13. Nuzzi R, Scalabrin S, Becco A, Panzica G (2019) Sex hormones and optic nerve disorders: a review. Front Neurosci 13:57. https://doi.org/10.3389/fnins. 2019.00057

14. Zhou X, Li F, Ge J, Sarkisian SR Jr, Tomita H, Zaharia A et al (2007) Retinal ganglion cell protection by 17-beta-estradiol in a mouse model of inherited glaucoma. Dev Neurobiol 67(5):603-616. https://doi.org/10.1002/dneu.20373

15. Prokai-Tatrai K, Xin H, Nguyen V, Szarka S, Blazics B, Prokai L et al (2013) 17ßestradiol eye drops protect the retinal ganglion cell layer and preserve visual function in an in vivo model of glaucoma. Mol Pharm 10(8):32533261. https://doi.org/10.1021/mp400313u

16. Russo R, Cavaliere F, Watanabe C, Nucci C, Bagetta G, Corasaniti MT et al (2008) 17Beta-estradiol prevents retinal ganglion cell loss induced by acute rise of intraocular pressure in rat. Prog Brain Res 173:583-590. https://doi. org/10.1016/S0079-6123(08)01144-8

17. Newman-Casey PA, Talwar N, Nan B, Musch DC, Pasquale LR, Stein JD (2014) The potential association between postmenopausal hormone use and primary open-angle glaucoma. JAMA Ophthalmol 132(3):298-303. https://doi.org/10.1001/jamaophthalmol.2013.7618

18. Dewundara SS, Wiggs JL, Sullivan DA, Pasquale LR (2016) Is estrogen a therapeutic target for glaucoma? Semin Ophthalmol 31(1-2):140-146. https://doi.org/10.3109/08820538.2015.1114845

19. Brodowska A, Brodowski J, Laszczyńska M, Słuczanowska-Głąbowska S, Rumianowski B, Rotter I et al (2014) Immunoexpression of aromatase cytochrome P450 and 17ß-hydroxysteroid dehydrogenase in women's ovaries after menopause. J Ovarian Res 7:52. https://doi.org/10.1186/17572215-7-52

20. Abramov Y, Borik S, Yahalom C, Fatum M, Avgil G, Brzezinski A et al (2005) Does postmenopausal hormone replacement therapy affect intraocular pressure? J Glaucoma 14(4):271-275

21. Affinito P, Di Spiezio SA, Di Carlo C, Sammartino A, Tommaselli GA, Bifulco $G$ et al (2003) Effects of hormone replacement therapy on ocular function in postmenopause. Menopause 10(5):482-487. https://doi.org/10.1097/01. GME.0000063568.84134.35

22. Altintaş O, Caglar Y, Yüksel N, Demirci A, Karabaş L (2004) The effects of menopause and hormone replacement therapy on quality and quantity of tear, intraocular pressure and ocular blood flow. Ophthalmologica 218(2): 120-129. https://doi.org/10.1159/000076148
23. Coksuer H, Ozcura F, Oghan F, Haliloglu B, Coksuer C (2011) Effects of estradiol-drospirenone on ocular and nasal functions in postmenopausal women. Climacteric 14(4):482-487. https://doi.org/10.3109/13697137.2010. 539724

24. Guaschino S, Grimaldi E, Sartore A, Mugittu R, Mangino F, Bortoli P et al (2003) Visual function in menopause: the role of hormone replacement therapy. Menopause 10(1):53-57

25. Özcan SC, Tolunay HE, Özcan DO, Adıbelli FM, Hilali NG, Kahraman K (2017) Does HRT change intraocular pressure in postmenopausal women? East J Med 22(2):53-56. https://doi.org/10.5505/ejm.2017.63825

26. Sator MO, Joura EA, Frigo P, Kurz C, Metka M, Hommer A et al (1997) Hormone replacement therapy and intraocular pressure. Maturitas 28(1):5558. https://doi.org/10.1016/s0378-5122(97)00060-1

27. Tint NL, Alexander P, Tint KM, Vasileiadis GT, Yeung AM, Azuara-Blanco A (2010) Hormone therapy and intraocular pressure in nonglaucomatous eyes. Menopause 17(1):157-160. https://doi.org/10.1097/gme.0b013e3181b82fb4

28. Toker E, Yenice O, Temel A (2003) Influence of serum levels of sex hormones on intraocular pressure in menopausal women. J Glaucoma 12(5):436-440

29. Vajaranant TS, Maki PM, Pasquale LR, Lee A, Kim H, Haan MN (2016) Effects of hormone therapy on intraocular pressure: the women's health initiativesight exam study. Am J Ophthalmol 165:115-124. https://doi.org/10.1016/j. ajo.2016.02.025

30. Kosior-Jarecka E, Sagan M, Wróbel-Dudzińska D, Łukasik U, Aung T, Khor CC et al (2019) Estrogen receptor gene polymorphisms and their influence on clinical status of Caucasian patients with primary open angle glaucoma. Ophthalmic Genet 40(4):323-328. https://doi.org/10.1080/13816810.2019. 1639201

31. Mabuchi F, Sakurada Y, Kashiwagi K, Yamagata Z, lijima H, Tsukahara S (2010) Estrogen receptor beta gene polymorphism and intraocular pressure elevation in female patients with primary open-angle glaucoma. Am J Ophthalmol 149(5):826-30.e1-2. https://doi.org/10.1016/j.ajo.2009.12.030

32. Chen X, Liu Y, Zhang Y, Kam WR, Pasquale LR, Sullivan DA (2018) Impact of aromatase absence on murine intraocular pressure and retinal ganglion cells. Sci Rep 8(1):3280. https://doi.org/10.1038/s41598-018-21475-x

33. Cohen LP, Pasquale LR. Clinical characteristics and current treatment of glaucoma. Cold Spring Harb Perspect Med 2014;4(6). pii: a017236. doi: https://doi.org/10.1101/cshperspect.a017236

34. Vranka JA, Kelley MJ, Acott TS, Keller KE (2015 Apr) Extracellular matrix in the trabecular meshwork: intraocular pressure regulation and dysregulation in glaucoma. Exp Eye Res 133:112-125. https://doi.org/10.1016/j.exer.2014.07. 014

35. Hill LJ, Mead B, Thomas CN, Foale S, Feinstein E, Berry M (2018) TGF- $\beta$ induced IOP elevations are mediated by RhoA in the early but not the late fibrotic phase of open angle glaucoma. Mol Vis 24:712-726

36. Agarwal P, Daher AM, Agarwal R (2015) Aqueous humor TGF- $\beta 2$ levels in patients with open-angle glaucoma: a meta-analysis. Mol Vis 21:612-620

37. Kasetti RB, Maddineni P, Patel PD, Searby C, Sheffield VC, Zode GS (2018) Transforming growth factor $\beta 2$ (TGF $\beta 2$ ) signaling plays a key role in glucocorticoid-induced ocular hypertension. J Biol Chem 293(25):9854-9868. https://doi.org/10.1074/jbc.RA118.002540

38. Matsuda T, Yamamoto T, Muraguchi A, Saatcioglu F (2001) Cross-talk between transforming growth factor-beta and estrogen receptor signaling through Smad3. J Biol Chem 276(46):42908-42914

39. Iorga A, Cunningham CM, Moazeni S, Ruffenach G, Umar S, Eghbali M (2017) The protective role of estrogen and estrogen receptors in cardiovascular disease and the controversial use of estrogen therapy. Biol Sex Differ 8(1):33. https://doi.org/10.1186/s13293-017-0152-8

40. Pasquale LR, Loomis SJ, Weinreb RN, Kang JH, Yaspan BL, Bailey JC et al (2013) Estrogen pathway polymorphisms in relation to primary open angle glaucoma: an analysis accounting for gender from the United States. Mol Vis 19:1471-1481

41. Tsuchiya Y, Nakajima M, Kyo S, Kanaya T, Inoue M, Yokoi T (2004) Human CYP1B1 is regulated by estradiol via estrogen receptor. Cancer Res 64(9): 3119-3125

42. Wang Z, Li M, Li L, Sun H, Lin XY (2015) Association of single nucleotide polymorphisms in the CYP1B1 gene with the risk of primary open-angle glaucoma: a meta-analysis. Genet Mol Res 14(4):17262-17272. https://doi. org/10.4238/2015.December.16.26

43. Zhao $Y$, Wang S, Sorenson CM, Teixeira L, Dubielzig RR, Peters DM et al (2013) Cyp1b1 mediates periostin regulation of trabecular meshwork 
development by suppression of oxidative stress. Mol Cell Biol 33(21):42254240. https://doi.org/10.1128/MCB.00856-13

44. Dong S, Yang J, Yu W, Kota P, Xia X, Xu H (2012) No association of genetic polymorphisms in CYP1B1 with primary open-angle glaucoma: a meta- and gene-based analysis. Mol Vis 18:786-796

45. Reis LM, Tyler RC, Weh E, Hendee KE, Kariminejad A, Abdul-Rahman $\mathrm{O}$ et al (2016) Analysis of CYP1B1 in pediatric and adult glaucoma and other ocular phenotypes. Mol Vis 22:1229-1238

\section{Publisher's Note}

Springer Nature remains neutral with regard to jurisdictional claims in published maps and institutional affiliations.

\section{Submit your manuscript to a SpringerOpen ${ }^{\circ}$ journal and benefit from:}

- Convenient online submission

Rigorous peer review

- Open access: articles freely available online

High visibility within the field

- Retaining the copyright to your article

Submit your next manuscript at $\boldsymbol{\nabla}$ springeropen.com 